\title{
Documentation of en route mortality of summer Chum Salmon in the Koyukuk River, Alaska and its potential linkage to the heatwave of 2019
}

\author{
Peter Westley ${ }^{1}$ \\ ${ }^{1}$ University of Alaska Fairbanks
}

May 6, 2020

\begin{abstract}
This paper documents a mass en route mortality event of adult summer chum salmon (Oncorhynchus keta) returning to the Koyukuk River, Alaska in the Yukon River watershed. In response to reports from local communities, researchers (including the author) surveyed ca. $315 \mathrm{~km}$ of river on July 26 and 27, 2019 and counted 1,364 dead individuals, but this likely reflects a small fraction of the true number of fish that died. We sampled 73 carcasses to confirm death occurred prematurely prior to complete maturation and spawning, to quantify sex and length. Visual inspection revealed a substantial fraction exhibited patterns of fungal growth consistent with secondary infections of skin lesions caused by the ubiquitous natural bacterial pathogen Flavobacterium columnare. Water temperatures during the survey averaged $17.1^{\circ} \mathrm{C}$ and the water was approximately $85 \%$ saturated with oxygen (ca. $8.5 \mathrm{mg} / \mathrm{L}$ ), which likely contributed to the stress for upstream migrants. Evidence suggests sizeselective en route mortality as female migrants that died were $2 \%$ and male migrants $5 \%$ shorter than individuals that survived to their spawning grounds on Henshaw Creek. This translates to very strong estimates of natural selection using standardized selection differentials, though randomization tests of size data revealed this observed outcome of selection was expected to occur $25 \%$ of the time due to chance alone. It is unclear whether selection acts on body size directly or indirectly through correlated phenotypic traits such as run timing. The mortality event likely underpins the below average returns of summer chum salmon to the Koyukuk in 2019, suggesting an impact on spawner abundance. The future consequences of this, or potentially increasingly frequent, en route mortality events for population productivity and the extent to which genetic adaptation or adaptive phenotypic plasticity of migration behavior may facilitate persistence of these populations is unknown.
\end{abstract}

\section{Introduction}

Prespawning mortality events in Pacific (genus Oncorhynchus ) salmon are well-documented throughout the ranges of species, but the mechanisms and consequences of these events for populations and ecosystems, including people, are not well known (Bowerman et al. 2016). Prespawning mortality events can occur at various stages of the upstream homeward migration. Upon reaching the spawning grounds, prespawning mortality (PSM) appears linked to spawner density and streamflow, which in turn influences the availability of life-supporting dissolved oxygen (Sergeant et al. 2017). Our understanding of PSM on the spawning grounds is largely limited to years with anomalously large returns (Quinn et al. 2007; Tillotson and Quinn 2017) or locations where spawner densities are influenced by returns of hatchery-produced salmon (McConnell et al. 2018). While our understanding of PSM on the spawning grounds is in its early phases, most of what we know has been garnered by studies tracking fish en route upstream during the freshwater phase of the homeward migration (Hinch et al. 2012).

Substantial work on large watersheds such as the Fraser River (British Columbia, Canada), Klamath River (USA), and the Columbia River (USA) has revealed that en route mortality events are the result of complex interactions between the phenotype of migrants (e.g. run timing and physiology) and their environment, 
with water temperature and flow being master variables (Keefer et al. 2008). As a poignant example, early migrating sockeye salmon $(O$. nerka $)$ in the Fraser River tend to die at much higher rates than later returning individuals, which appears to be associated with a mismatch between current warm water conditions and thermal adaptation in terms of aerobic scope to historical migration conditions (Eliason et al. 2011). In contrast, later-timed migrants of Sockeye Salmon died at higher rates in the Columbia River during 2000, likely due to delayed migration and increased susceptibility to parasite and pathogens (Keefer et al. 2007). Perhaps the best known example of a temperature-related disease outbreak is from the Klamath River in September of 2002, where an estimated 34,056 migrating Chinook salmon (O. tshawytscha) died as a result of heavy infections ofIchthyopthirius multifiliis (Ich) and/or Flavobacterium columnare (columnaris) (Guillen 2003). Of course, a perennial challenge is disentangling whether pathogen presence and disease is the proximate agent of mortality or, more commonly in wild fish, a response to other unquantified stressors. Taken as a whole, strong evidence indicates that the combination of high water temperatures, accelerated maturation and senescence, elevated stress, ionoregulatory dysfunction, and disease are the causal agents behind en route mortality in migrating salmon (Hinch et al. 2012). Moreover, patterns observed thus far indicate that populations at the southern margins of the ranges may be most susceptible to en route mortality given regional warming that increasingly push water temperatures beyond tolerance thresholds. In this paper I document, a large-scale en route mortality event by summer Chum Salmon (O. keta) returning to spawning grounds on the edge of the Arctic in the Yukon River watershed, Alaska (Fig.1).

The summer of 2019 will forever be burned in the consciousness of Alaskans. Most apparent was the extreme air temperature anomalies with many regions, including the Yukon, experiencing many days with maximum temperatures in excess of $32^{\circ} \mathrm{C}$. Temperatures in July and August were far above average compared to long-term records (Fig. 2). In addition, ocean temperatures in Alaska were 5 degrees warmer than average, wildfires burned throughout the state choking the air with smoke, droughts plagued rain forests, a lack of sea ice in the Bering Sea, and anomalous biological patterns were detected across the region (Thoman and Walsh 2019). Beginning on July 20th, the residents living along the Koyukuk River that have long been the stewards and first responders on their lands began reporting a large scale die-off of Chum Salmon on social media outlets. Hundreds of comments and similar observations streamed in, and on July $26^{\text {th }}$ a dispatch of western-trained scientists, including the author, traveled to the Koyukuk River drainage with the goals of $i$ ) documenting the extent of the die-off, $i i$ ) inferring any apparent abiotic or biotic causes of the event, and iii ) quantifying whether mortality was associated with body size or sex by comparing to observations of fish that survived to the spawning grounds.

\section{Methods}

\section{Site description}

The Yukon River watershed is massive, draining approximately $850,000 \mathrm{~km}^{2}$ and flowing more than 3,000 $\mathrm{km}$ from its source in Canada to the Bering Sea of Alaska. Made famous in the writings of resident Syndey Huntington (Huntington 1993), the Koyukuk River drains $83,000 \mathrm{~km}^{2-}$ and flows ca. $725 \mathrm{~km}$ before its confluence with the Yukon River where water flows another ca. $775 \mathrm{~km}$ to the ocean. Summer Chum Salmon of the Koyukuk are primarily destined to spawning grounds on the Gisasa River and Henshaw Creek (Janzen and Stern 1998), where weirs allow the quantification of spawner numbers and documentation of age, sex, and length of returning adults. Examination of size selective en route mortality (see below) was done only using data from Henshaw Creek as our survey was done upstream of the Gisasa River confluence with the Koyukuk. The Koyukuk River is a major producer of summer chum salmon; extensive telemetry tracking of 2,431 migrating salmon in 2014 and 2015 revealed approximately one out of every four fish return to the Koyukuk and its tributaries (Larsen et al. 2017).

\section{Documenting en route mortality and carcass sampling}

With the help of local residents with deep-time knowledge of the Koyukuk River, we surveyed approximately $250 \mathrm{~km}$ via jet boat, beginning at the village of Hughes $(66.05 \mathrm{~N},-154.28 \mathrm{~W})$ and traveling downstream to the community of Huslia $(65.69 \mathrm{~N},-156.38 \mathrm{~W})$. While traveling we counted the number of carcasses floating in 
the river and those that were clearly visible along sandbars and shore banks. On an ad hoc basis and as time allowed, we stopped and surveyed along the river banks where we, $i$ ) counted the number of carcasses along approximately $0.5 \mathrm{~km}$ upstream and downstream of the landing site and noted characteristics of carcasses including external signs of scavenging or disease (e.g. fungal growth on fins or gills), ii ) recorded the sex and maturation status of dead fish confirmed through internal examination, iii ) recorded water temperature and dissolved oxygen $(\mathrm{mg} / \mathrm{L})$ using a handheld YSI PRO 2030 model multimeter, and $i v$ ) measured the body length of carcasses to the nearest millimeter between the middle of the eye and fork of the tail. Due to decomposition of the tail on 36 individuals, length was measured between the middle of the eye and the hypural flexure and adjusted to mid-eye fork length using the equation derived from the data $\left(\mathrm{r}^{2}=0.92\right)$ :

$$
\mathrm{MEF}_{\text {est }}=1.00 * \mathrm{MEH}_{\mathrm{obs}}+52.5
$$

Where $\mathrm{MEF}_{\text {est }}$ is the estimated middle eye to fork $(\mathrm{mm})$ and $\mathrm{MEH}_{\text {obs }}$ is the observed middle eye to hypural measurement $(\mathrm{mm})$.

Selection and the role of body size in migration

Binomial logistic regression following Janzen and Stern (1998) was used to investigate the potential role of body size mediating the success (or absolute fitness) of upstream migrating individuals. Specifically, the fate of individuals as alive vs. dead was coded binomially as a zero or one and used as the response variable in a generalize linear model. Fixed effects of measured body size (at weirs for the alive individuals and from surveys for the dead individuals) and a categorical effect of sex were included in the model with binomial error structure and a logit link function.

To quantify the magnitude of the estimated selection acting on length, I calculated the standardized selection differential following Kendall et al. (2009), using the equation

$\left(X_{\text {Alive }}-X_{\text {Dead }}\right) / \mathrm{SD}_{\text {Alive }+ \text { Dead }}$

Where $X_{\text {Alive }}$ is the mean $(\mathrm{mm})$ of fish measured at weirs on the spawning grounds and $X_{\text {Dead }}$ is the mean of $(\mathrm{mm})$ of fish to have died en route, and $\mathrm{SD}_{\text {Alive }+ \text { Dead }}$ is the pooled standard deviation of all length measurements (alive + dead). Standardized selection differentials measure total selection acting on traits though both direct and indirect agents. To quantify uncertainty in selection estimates, I conducted 10,000 randomization simulations through the following procedure. For each simulation, the pooled distribution of all lengths (alive + dead) was sampled with replacement 500 times and used to calculate means for alive and dad individuals that were then used to calculate a standardized selection differential. The observed standardized selection differential calculated from the field was compared to the simulated distribution of differentials to better understand the probability of the observed strength of selection occurring through chance alone. Strength of selection was compared to a recently compiled dataset by (Siepielski et al. 2017).

\section{Results}

Consistent with the flood of local observations of a die-off, we encountered the first carcasses floating midriver nearly immediately upon leaving Hughes. In the ca. $315 \mathrm{~km}$ of survey, we counted 1,364 dead fish.

Sampled carcasses varied markedly in condition and state of decomposition. None of the carcasses had signs of trauma or post-mortem scavenging by animals, a pattern that was also widely noted by local residents. Every individual examined internally for sex had not completed maturation, indicated by firm testes in males and unovulated eggs in females (Fig. 3). Approximately $1 / 3$ of the carcasses had signs of potential fungal growth, consistent with secondary infections following the growth of Flavobacterium columnare ( James Winton, USGS, personal communication).

The water temperature in the mainstem Koyukuk River during the survey averaged $17.1^{\circ} \mathrm{C}$ (range $16.8-$ 17.4). Dissolved oxygen averaged $8.3 \mathrm{mg} / \mathrm{L}$ (Range $7.9-8.6$ ). Given that DO saturation at $17.1^{\circ} \mathrm{C}$ occurs 
at $9.65 \mathrm{mg} / \mathrm{L}$, our measurements indicate the water was on average only approximately $87 \%$ saturated with dissolved oxygen.

Consistent with size-selective mortality, individuals that died en route were ca. $4 \%$ smaller on average compared to individuals that survived to the spawning grounds (Table 1). Body size was significantly and inversely associated with probability of death (Fig. 4, $\mathrm{p}<0.0001$ ) Estimates of standardized selection for males was 0.77 , and 0.86 for females. These estimates exceed the $99^{\text {th }}$ percentile of estimates reported by Siepielski et al. and is thus evidence of very strong selection. However, simulation analysis indicate that our observations of selection could have occurred approximately $25 \%$ of the time due to chance alone, which likely reflects the natural wide distribution of body sizes in summer Chum Salmon.

\section{Discussion}

This paper documents substantial en route mortality of migrating summer Chum Salmon a major tributary of the Yukon River, the Koyukuk River, in Alaska during the summer of 2019. Although the true numbers of fish that died during this event and the proximate mechanisms of the mortality are not known, available evidence points to a temperature-mediated phenomenon. Comparisons of body size between individuals that successfully accomplished their migrations vs. those that died en route revealed evidence of size-selective mortality favoring larger body sizes, but whether this reflects direct selection acting on size or indirect selection acting on correlated phenotypic traits is unclear. The ultimate question of how this event will impact future summer Chum Salmon production in subsequent years remains to be seen. The lower than average escapement counts observed on the major spawning grounds of Henshaw Creek and the Gisasa River suggests that theen route mortality event was substantial enough to impact the number of spawners surviving at the population level, which raises conservation concerns should die-offs become more frequent and/or greater in severity.

Over a thousand dead fish were counted along a $250 \mathrm{~km}$ section of the Koyukuk River during a rapid-response survey on July 26-27, 2019. This work would not have been possible without the invaluable observations of local residents and the use of social media to communicate among communities and with scientists and managers. Local residents have always been the first responders to extreme events, and mechanisms to support communities' on-going stewardship of the river and its salmon are needed more than ever. The magnitude of the die-off is unknown, but likely substantial given several lines of evidence. First, the survey occurred over a short time period (ca. 1.5 days) and over a relatively small portion of the migratory path. Second, according to local residents and the observed state of carcasses decomposition, it was clear that the survey occurred after the peak of the event, suggesting that counts would have been higher if we had been able to survey the river a few days earlier. Third, carcass counts while traveling were an unknown, but obviously minor, fraction of the number deposited on shore, which in turn is an unknown fraction of the total number that died throughout the drainage. Given the scarcity of data, it is impossible to estimate what the total fraction of the returning fish succumbed toen route mortality. However, observed counts at the two major spawning grounds were below average (Fig. 5), which is attributed by managers to the warm temperatures and observed en route mortality (Brenner et al. 2020). Between 1999 and 2018, Henshaw Creek had averaged 159,000 spawners and between 1994 and 2018 Gisasa River averaged 66,736 spawners. The observations of 34,342 and 19,099 spawners were the fourth smallest on record for both Henshaw Creek and the Gisasa River. It is possible that the anomaly between average and observed escapements was larger for the Henshaw Creek population given the greater energetic demands for populations that must travel further upstream to spawning grounds compared to other populations (Crossin et al. 2004) in addition to the difference in accumulated time in stressful migrating conditions (Hinch et al. 2012).

Although the proximate mechanisms of this en route mortality event are not known, existing evidence is strongly consistent with temperature-mediated effects observed in other locations (Hinch et al. 2012). First, hypoxic conditions may have contributed to the stress of migrants given that measurements of dissolved oxygen indicated approximately $87 \%$ saturation. It is important to note that migrating individuals require substantially more oxygen than individuals that are not actively migrating (Brett 1972). Second, summer Chum Salmon returning to the Koyukuk were approximately 8 days later than average (Brenner et al. 2020), 
which is consistent with the widely observed pattern of delayed migrations in other systems during periods of anomalously warm water. For example, Chinook Salmon in the Klamath River during 2002 entirely ceased migration when the water temperature rose above ca. 20 degrees $\mathrm{C}$, which in turn increased their densities in cool water holding refugia and contributed to the spread of pathogens, particularly Ich and columnaris that ultimately inflicted mass mortality (Strange 2010, 2013). Third, observed water temperatures during the time of the survey averaged $17.1^{\circ} \mathrm{C}$, which is above the optimum temperature for migration and is known to put individuals at risk of increased mortality from pathogens such as F. columnare (Holt et al. 1975). Approximately a third of the carcasses were noted to have patches of fungal growth, consistent with earlier infections with columanaris or other bacterial pathogen (Fig. 3), but formal pathology was not conducted. Future rapid response surveys should be prepared to take pathology samples to provide diagnostic disease assessments. Importantly, the individual fish we sampled as carcasses on the mainstem Koyukuk had already traveled $900 \mathrm{~km}$ from the mouth of the Yukon River and it is likely that the accumulated time traveling in warm water, combined with delayed migration increased the susceptibility to pathogens, similar to en route mortality events in the Fraser River and Columbia River.

We detected evidence of size-selective mortality, where individuals that died en route were approximately $4 \%$ shorter than individuals that survived to the spawning grounds at the Henshaw Creek weir (Fig. 4). This pattern was observed in both males and females and was estimated to be strong selection compared to a global database of standardized selection differentials (Siepielski et al. 2017). However, several important caveats with the analysis are necessary. First, like many analyses of selection this one is plagued by small and unbalanced sample sizes (68 dead vs. 553 alive). Randomization simulations conducted on the combined dataset (alive + dead) revealed that the level of selection observed was likely to occur 1 out of every 4 times due to chance alone. Second, the carcass survey occurred over a much narrower range of dates than the observations at the weir, which may bias results particularly because the size and age of individuals returning to spawning grounds often covaries with run timing (Quinn et al. 2015). Indeed, the size of returning individuals to the Henshaw Weir declined significantly throughout the run $(\mathrm{p}<0.001)$, but date explained little of the variance $(6 \%)$ in size. However, analyses using a date-truncated dataset from the Henshaw weir revealed similar patterns of size selection with large fish being favored to return, and thus the pattern was consistent while including the potential effect of run timing. Third, it is not clear whether size selectivity is the result of direct selection acting on body size or is the result of both direct and indirect selection acting on correlated phenotypic traits such as physiological tolerances and others that comprise a migratory phenotype. The selection analysis here assumes only direct selection, which is likely not true. Future work to survey carcasses throughout the run and to gather additional phenotypic measurements would be needed to formally calculate selection gradients that allow quantification of direct and indirect influences on selection.

Will the en route mortality that occurred in 2019 have a lasting consequence on the populations in the Koyukuk River and how might populations adapt to warming? While this event gives cause for concern given it appears to have resulted in substantially below average spawner escapements, there are also reasons for optimism. Pacific salmon are remarkably productive and resilient in the face of disturbance (Hilborn et al. 2003) and there is little evidence that small spawner numbers can result in positive density-density dependent effects, also known as Allee Effects or depensation (Cunningham et al. 2013). The variable age of adult migrants contributing to any one return year (e.g. fish that spent 2, 3, or 4 winters at sea) provides a natural buffer that will likely dampen (or mask) the true effect of the die-off in future years (Schindler et al. 2010). In contrast, species such as pink salmon (O. gorbuscha) that all mature at two years of age, might be particularly vulnerable to mortality events. Consistent with observations from other systems in the southern part of the Pacific salmon range, it seems the most obvious response to this and potential future events are shifts in run timing by adults to avoid migrations during stressful periods (Quinn and Adams 1996). Indeed, run timing and migratory behavior, which reflect both plastic and genetic components, are predicted to shift earlier in many systems (Crozier et al. 2011; Reed et al. 2011a). Of course the extent to which run timing may shift is a function of the strength of selection and heritability in addition to plasticity (Carlson and Seamons 2008; Reed et al. 2011b). It is important to recall, however, that run timing is in part also shaped by the selection acting on other parts of the life history, such as the timing of spawning 
given the water temperature during incubation (Brannon et al. 2004). This presents potential conflicts, as selection may favor earlier return timing on the adult life history to avoid stressful water temperatures, whereas warming should select forlater timing given the relationship with temperature, embryo development, and match-mismatch dynamics. This dynamic selection tug-of-war is worthy of additional exploration using eco-evolutionary modeling.

While the short-term or long-term consequences of 2019 remains to be seen and understood, it is increasingly clear that regional warming throughout Alaska and the Arctic is likely to make these events more frequent and of greater severity. Preparations need to be made to avoid, to the extent possible, surprises like this that are on the horizon. This stark reality underscores the need to protect habitats that serve as the template for life history variation that buffers against disturbance (Moore et al. 2014), ensure migrating individuals have natural options to seek thermal refugia in cooler waters during stressful periods (Armstrong et al. 2016), and support local human communities to continue being the first responders and stewards of salmon, without which all of us would be impoverished.

\section{Acknowledgements}

Thanks to Stephanie Quinn-Davidson and Holly Carroll for their assistance and comradery on the Koyukuk. Fred West kindly provided historical escapement estimates, and Jim Winton was instrumental in pointing me to literature and educating me on all things columnaris. Marta Ulaski aided with comparisons of selection to the global database. Holly Carroll, Fred West, Zach Liller, and Jim Winton substantially improved the manuscript based on their comments. I, along with all Alaskans, are deeply indebted to the residents of the region that have been and continue to be stewards of the river. Funding for the survey was provided by the Yukon River Inter-tribal Fisheries Commission.

\section{Data Availability Statement}

Data are archived and freely available on the KNB database at: doi.xxxxxxx

References

Armstrong, J. B., E. J. Ward, D. E. Schindler, and P. J. Lisi. 2016. Adaptive capacity at the northern front: sockeye salmon behaviourally thermoregulate during novel exposure to warm temperatures. Conservation Physiology 4(1). Oxford Academic.

Bowerman, T., M. L. Keefer, and C. C. Caudill. 2016. Pacific Salmon Prespawn Mortality: Patterns, Methods, and Study Design Considerations. Fisheries 41(12):738-749.

Brannon, E. L., M. S. Powell, T. P. Quinn, and A. Talbot. 2004. Population Structure of Columbia River Basin Chinook Salmon and Steelhead Trout. Reviews in Fisheries Science 12(2-3):99-232.

Brenner, R. E., S. J. Larsen, A. Munro, and A. M. Carroll. 2020. Run Forecasts and Harvest Projections for 2020 Alaska Salmon Fisheries and Review of the 2019 Season.

Brett, J. R. 1972. The metabolic demand for oxygen in fish, particularly salmonids, and a comparison with other vertebrates. Respiration Physiology 14(1):151-170.

Carlson, S. M., and T. R. Seamons. 2008. SYNTHESIS: A review of quantitative genetic components of fitness in salmonids: implications for adaptation to future change: Quantitative genetics of charr, salmon, and trout. Evolutionary Applications 1(2):222-238.

Crossin, G. T., S. G. Hinch, A. P. Farrell, D. A. Higgs, A. G. Lotto, J. D. Oakes, and M. C. Healey. 2004. Energetics and morphology of sockeye salmon: effects of upriver migratory distance and elevation. Journal of Fish Biology 65(3):788-810.

Crozier, L. G., M. D. Scheuerell, and R. W. Zabel. 2011. Using time series analysis to characterize evolutionary and plastic responses to environmental change: a case study of a shift toward earlier migration date in sockeye salmon. The American Naturalist 178(6):755-773. University of Chicago Press Chicago, IL. 
Cunningham, C. J., G. T. Ruggerone, and T. P. Quinn. 2013. Size selectivity of predation by brown bears depends on the density of their sockeye salmon prey. The American Naturalist 181(5):663-673. University of Chicago Press Chicago, IL.

Eliason, E. J., T. D. Clark, M. J. Hague, L. M. Hanson, Z. S. Gallagher, K. M. Jeffries, M. K. Gale, D. A. Patterson, S. G. Hinch, and A. P. Farrell. 2011. Differences in Thermal Tolerance Among Sockeye Salmon Populations. Science 332(6025):109-112. American Association for the Advancement of Science.

Guillen, G. 2003. Klamath River Fish Die-off, September 2002: Report on Estimate of Mortality. U.S. Fish and Wildlife Service, Arcata Fish and Wildlife Office.

Hilborn, R., T. P. Quinn, D. E. Schindler, and D. E. Rogers. 2003. Biocomplexity and fisheries sustainability. Proceedings of the National Academy of Sciences 100(11):6564-6568.

Hinch, S. G., S. J. Cooke, A. P. Farrell, K. M. Miller, M. Lapointe, and D. A. Patterson. 2012. Dead fish swimming: a review of research on the early migration and high premature mortality in adult Fraser River sockeye salmon Oncorhynchus nerka. Journal of Fish Biology 81(2):576-599.

Holt, R. A., J. E. Sanders, J. L. Zinn, J. L. Fryer, and K. S. Pilcher. 1975. Relation of water temperature to Flexibacter columnaris infection in steelhead trout (Salmo gairdneri), coho (Oncorhynchus kisutch) and chinook (O. tshawytscha) salmon. Journal of the Fisheries Board of Canada 32(9):1553-1559. NRC Research Press.

Huntington, S. 1993. Shadows on the Koyukuk: an Alaskan native's life along the river. Alaska Northwest Books.

Janzen, F. J., and H. S. Stern. 1998. Logistic Regression for Empirical Studies of Multivariate Selection. Evolution 52(6):1564.

Keefer, M. L., C. A. Peery, and M. J. Heinrich. 2008. Temperature-mediated en route migration mortality and travel rates of endangered Snake River sockeye salmon. Ecology of Freshwater Fish 17(1):136-145.

Kendall, N. W., J. J. Hard, and T. P. Quinn. 2009. Quantifying six decades of fishery selection for size and age at maturity in sockeye salmon. Evolutionary Applications 2(4):523-536.

Larsen, S. D., H. C. Carroll, J. M. Conitz, and B. M. Borba. 2017. Abundance, distribution, and migration patterns of summer chum salmon in the Yukon River drainage, 2014-2015.

McConnell, C., P. Westley, and M. McPhee. 2018. Differences in fitness-associated traits between hatchery and wild chum salmon despite long-term immigration by strays. Aquaculture Environment Interactions 10:99-113.

Moore, J. W., J. D. Yeakel, D. Peard, J. Lough, and M. Beere. 2014. Life-history diversity and its importance to population stability and persistence of a migratory fish: steelhead in two large $\mathrm{N}$ orth A merican watersheds. Journal of Animal Ecology 83(5):1035-1046. Wiley Online Library.

Quinn, T. P., and D. J. Adams. 1996. Environmental changes affecting the migratory timing of American shad and sockeye salmon. Ecology 77(4):1151-1162. Wiley Online Library.

Quinn, T. P., D. M. Eggers, J. H. Clark, and Jr. Rich H. B. 2007. Density, climate, and the processes of prespawning mortality and egg retention in Pacific salmon (Oncorhynchus spp.). Canadian Journal of Fisheries and Aquatic Sciences 64(3):574-582. NRC Research Press.

Quinn, T. P., P. McGinnity, and T. E. Reed. 2015. The paradox of "premature migration" by adult anadromous salmonid fishes: patterns and hypotheses. Canadian Journal of Fisheries and Aquatic Sciences 73(7):1015-1030. NRC Research Press.

Reed, T. E., D. E. Schindler, M. J. Hague, D. A. Patterson, E. Meir, R. S. Waples, and S. G. Hinch. 2011a. Time to Evolve? Potential Evolutionary Responses of Fraser River Sockeye Salmon to Climate Change and 
Effects on Persistence. PLoS ONE 6(6):e20380.

Reed, T. E., D. E. Schindler, and R. S. Waples. 2011b. Interacting Effects of Phenotypic Plasticity and Evolution on Population Persistence in a Changing Climate: Evolution, Plasticity, and Climate Change. Conservation Biology 25(1):56-63.

Schindler, D. E., R. Hilborn, B. Chasco, C. P. Boatright, T. P. Quinn, L. A. Rogers, and M. S. Webster. 2010. Population diversity and the portfolio effect in an exploited species. Nature 465(7298):609-612.

Sergeant, C. J., J. R. Bellmore, C. McConnell, and J. W. Moore. 2017. High salmon density and low discharge create periodic hypoxia in coastal rivers. Ecosphere 8(6):e01846.

Siepielski, A. M., M. B. Morrissey, M. Buoro, S. M. Carlson, C. M. Caruso, S. M. Clegg, T. Coulson, J. DiBattista, K. M. Gotanda, C. D. Francis, J. Hereford, J. G. Kingsolver, K. E. Augustine, L. E. B. Kruuk, R. A. Martin, B. C. Sheldon, N. Sletvold, E. I. Svensson, M. J. Wade, and A. D. C. MacColl. 2017. Precipitation drives global variation in natural selection. Science 355(6328):959-962. American Association for the Advancement of Science.

Strange, J. S. 2010. Upper Thermal Limits to Migration in Adult Chinook Salmon: Evidence from the Klamath River Basin. Transactions of the American Fisheries Society 139(4):1091-1108.

Strange, J. S. 2013. Factors influencing the behavior and duration of residence of adult Chinook salmon in a stratified estuary. Environmental Biology of Fishes 96(2-3):225-243.

Thoman, R., and J. Walsh. 2019. Alaska's changing environment: documenting Alaska's physical and biological changes through observations.

Tillotson, M. D., and T. P. Quinn. 2017. Climate and conspecific density trigger pre-spawning mortality in sockeye salmon (Oncorhynchus nerka). Fisheries Research 188:138-148.

Tables

\section{Hosted file}

image1.emf available at https://authorea.com/users/317662/articles/447746-documentation-ofen-route-mortality-of-summer-chum-salmon-in-the-koyukuk-river-alaska-and-its-potentiallinkage-to-the-heatwave-of-2019 


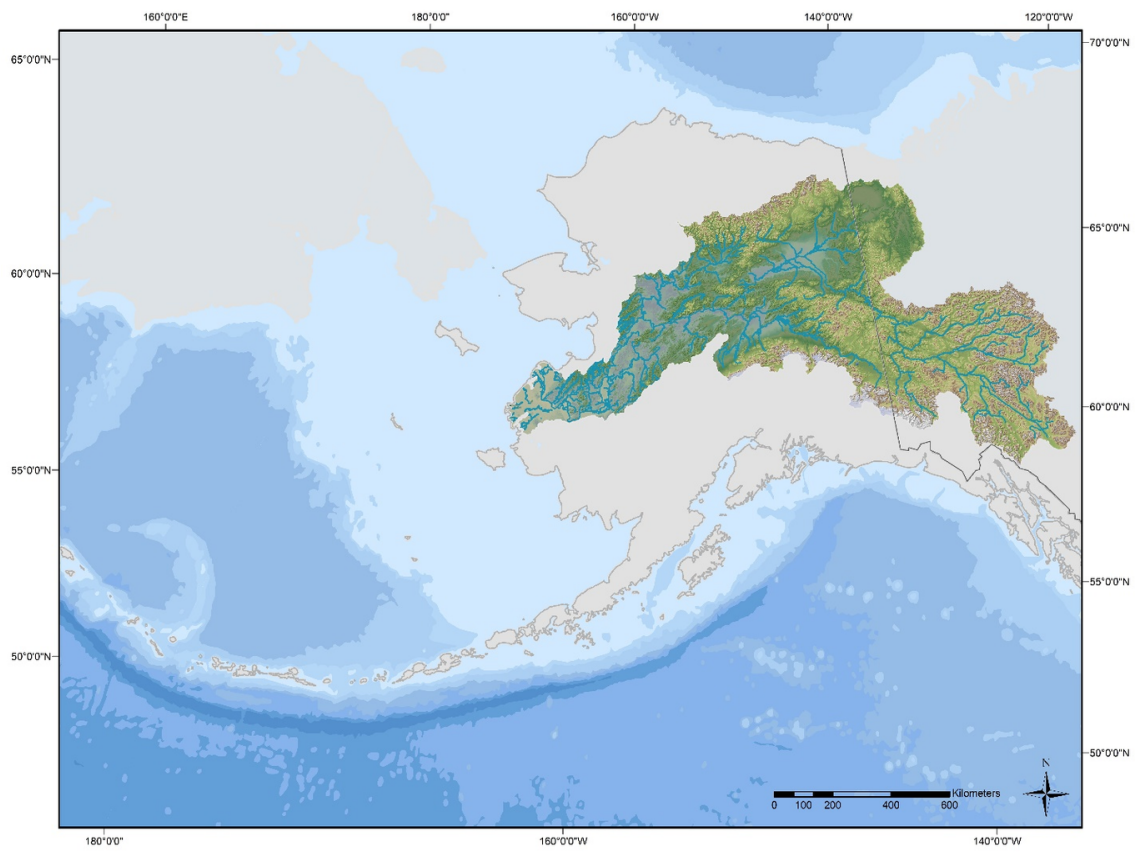

Figures

Figure 1. Approximately location (shown as red star) of the 2019 survey that documented en route mortality of summer chum salmon on the Koyukuk River, a major tributary in the Yukon River watershed (shown in green).

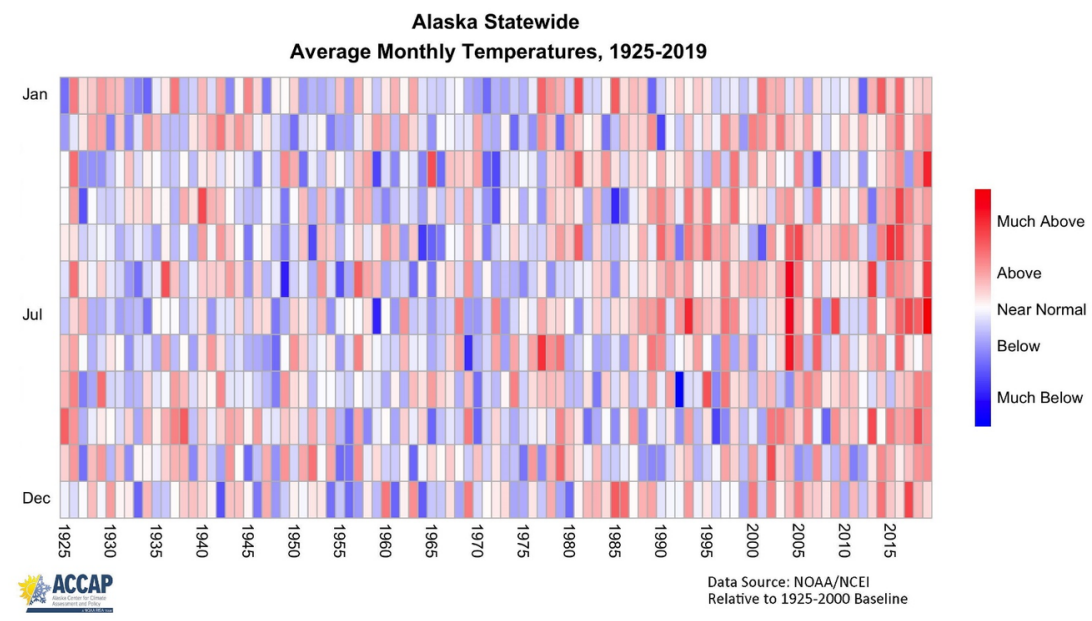

Figure 2. Monthly air temperature anomalies from 1925-2019. 


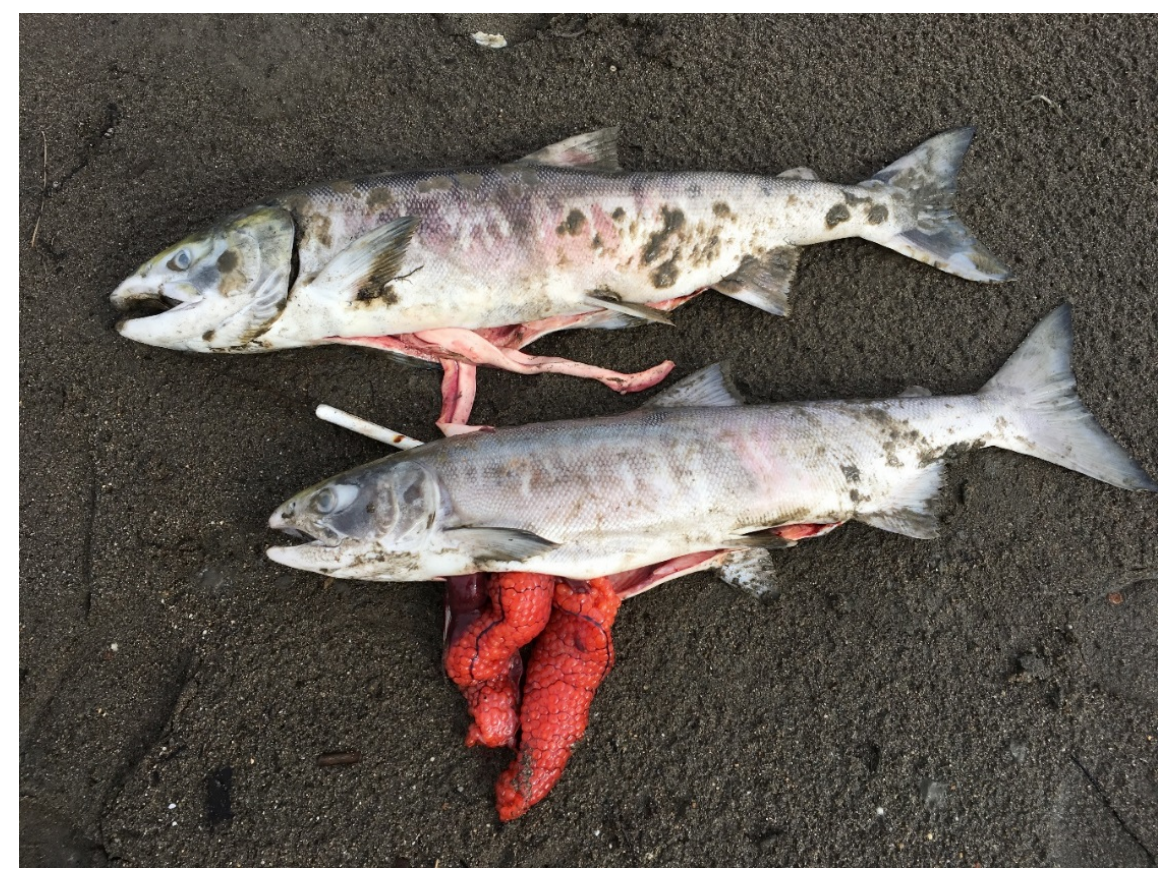

Figure 3. Photo of male (top) and female (bottom) summer chum salmon surveyed on the Koyukuk River, July 26, 2019. Note the immature status of the testes on the male and ova of the female. Also note the patches of fungus consistent with prior infection with the bacterial pathogen $F$. columnare. Photo credit Stephanie Quinn-Davidson.

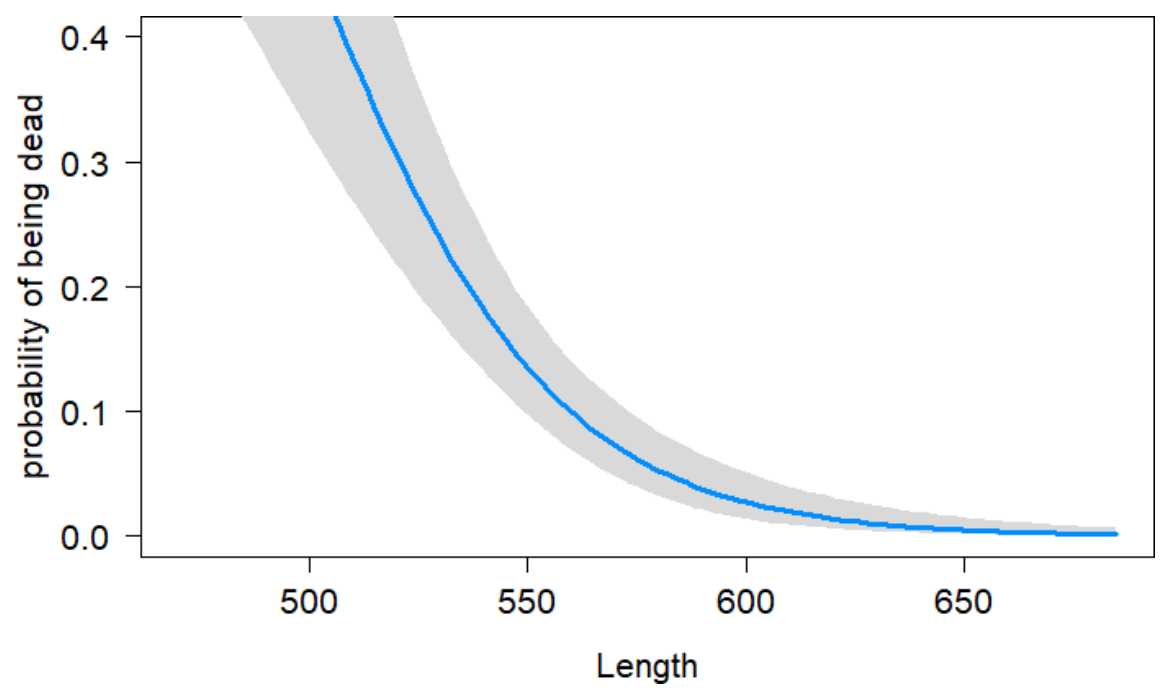

Figure 4. Probability of en route mortality declined with size. The blue line is the median estimate from a bionomial logistic regression with effects of body length and sex and the grey polygon is the $95 \%$ confidence interval of the estimate. Inset boxplots of length of fish that were measured alive at the Henshaw Creek weir (blue) and those surveyed dead en route on the Koyukuk River mainstem (red). 


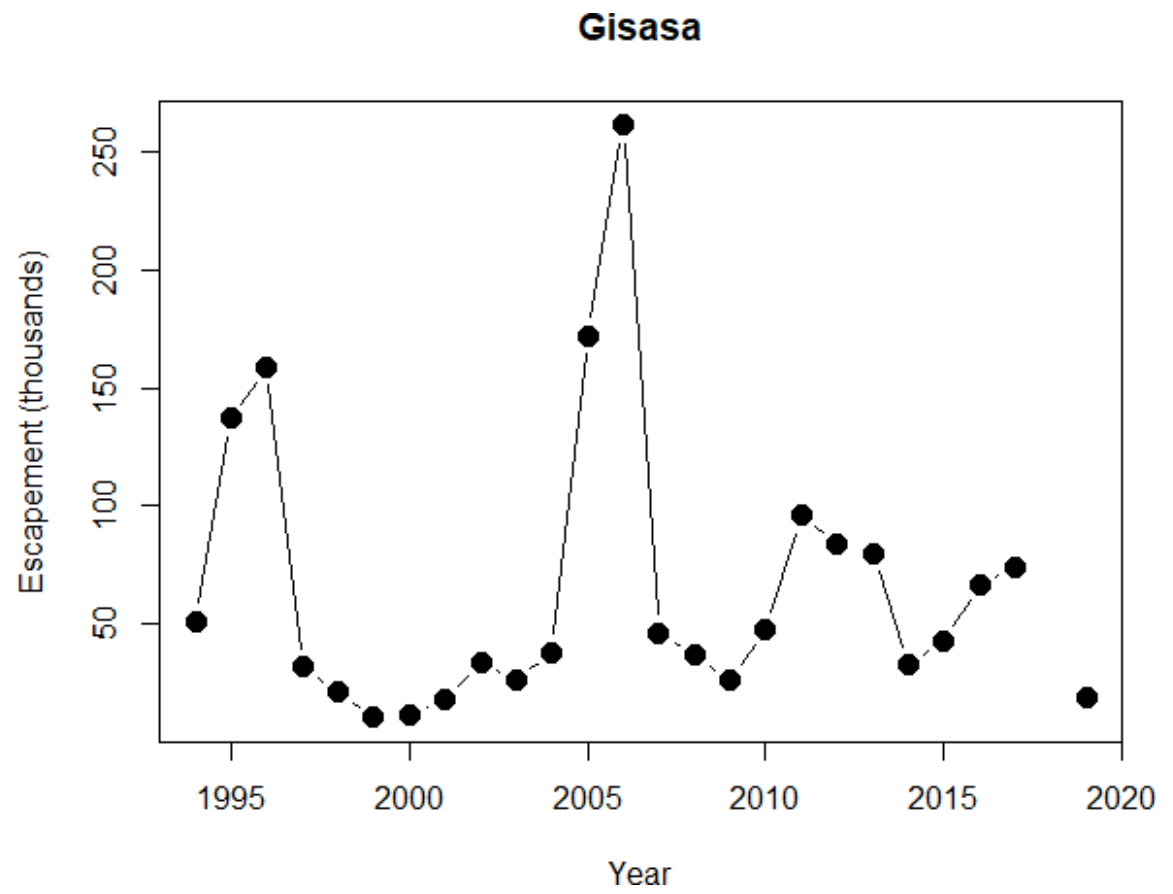

Figure 5. Annual escapement estimates (in thousands) of summer chum salmon for the Henshaw Creek (1999-2019) and Gisasa River (1994-2019). Estimates for 2019 are 34,342 in Henshaw Creek and 19,099 in Gisasa River. 